\title{
S. W. D. K. GANDAH (1927-2001): INTELLECTUAL AND HISTORIAN FROM NORTHERN GHANA
}

\section{Carola Lentz}

S. W. D. K. Gandah, or 'Kum', as he was affectionately called by his family and friends, was the son of an influential chief in Lawra District in what is today north-western Ghana. His father was enskinned as Birifu Naa Gandah I in 1917 and came to play an important role in the colonial chiefly politics of the region. Kumbonoh grew up as one of more than a hundred sons and daughters of the chief and witnessed first-hand the way the conflicts, pressures and transformations of colonial rule played out on the ground in northern Ghana. He belonged to the first generation of educated northerners. Like many of this generation, he prized his literary and intellectual attainments, and sought to extend them and put them to original use throughout his life. The text we present here is evidence of his activity and self-conception as a local intellectual. It is an idiosyncratic history and biography of his father, 'a man of great foresight' in Kum's estimation. It sheds light both on the colonial encounter in rural northern Ghana, and on the values and attitudes of an emergent white-collar class invested in local affairs but also critical of them.

Kumbonoh was born into the Naayile patriclan in Birifu, a village in Lawra District, in 1927. He was among the first group of students to enter the re-opened Lawra Confederacy Native Authority Primary School, which he attended from 1935 to 1939. From 1940 to 1944, he continued his education at Tamale Government Middle Boarding School-at that time the only state-run postprimary educational institution in what were then the Northern Territories of the Gold Coast. Like many of his educated classmates, having reached 'standard seven', he enrolled in the Tamale Teacher Training College, from which he graduated in 1946. For a few years, he taught at his own former primary school in Lawra, but soon left, to work in the family transport and retail business that he had helped establish and, more importantly, to become engaged in party politics. Actively supporting the 'mass education' programme and becoming involved in the People's Education Association in Tumu in the early 1950s, he was elected to both the Local and District Councils. Between 1954 and 1956 he helped to organize the Northern People's Party (NPP) in the north-west and served as the

Carola Lentz is Professor of Social Anthropology in the Department of Anthropology and African Studies of Johannes Gutenberg University, Mainz. Since 1987 she has been conducting research on labour migration, ethnicity, the history of chieftaincy, land rights, and the politics of belonging in northern Ghana and Burkina Faso. Her current research project explores the changing career strategies and home ties of the members of an emerging middle class in northern Ghana. She also supervises a group of junior researchers who have studied the 2010 African independence celebrations in nine different countries. She is author of Ethnicity and the Making of History in Northern Ghana (Edinburgh University Press and the International African Institute, 2006), Land, Mobility and Belonging in West Africa (Indiana University Press, forthcoming) as well as other monographs and numerous journal publications, and she has edited, among others, Land and the Politics of Belonging in West Africa (Brill, 2006). She is president of the German Anthropological Association. Email: lentz@uni-mainz.de

(C) International African Institute 2012 
personal secretary of S. D. Dombo, one of the leading opposition politicians under the Nkrumah regime.

Despite his active engagement in party politics, Gandah never relaxed his efforts to further his education. He regularly participated in the annual New Year holiday schools organized by the Department of Extra Mural Studies of the University College of the Gold Coast in collaboration with the People's Education Association; listening to speeches by eminent British and Ghanaian lawyers, politicians and professionals, he became friends with some of the British tutors from University College London who organized these extramural activities, like David Kimble, Dennis Austin and Bill Tordoff. He repeatedly applied for scholarships to study abroad, but for various reasons did not succeed. Nevertheless, using money that he was able to set aside from his business, Gandah finally travelled to London in 1956, where he joined his schoolmate and friend Hilla Limann. Limann, also from the north-west, had left for London a year earlier in order to obtain his GCE (General Certificate of Education) O and A levels to study law; much later, in 1979, he was to become Ghana's first president from the north. With Limann's help, Gandah found a college in London where he pursued courses for his GCE exams, which he passed a year after his arrival, and then enrolled to study economics at the London School of Economics. Throughout, he supported himself by taking on various holiday jobs, until he eventually found regular employment with British Rail that allowed him to continue his studies while working. Having pursued courses in statistics and the philosophy of science, in the mid-1960s Kumbonoh Gandah was finally hired as a statistician by the Guinness brewery.

Despite buying a flat in London and sponsoring the immigration to the United Kingdom of his two children, whom he had left behind in Ghana, Gandah always maintained close ties with his home country, and regularly visited his family and friends. He even decided to retire early from the Guinness company and return to Ghana to establish a business. But during one of his preparatory visits home, in 1983, he was involved in a terrible car accident that forced him to spend many months in hospitals in Ghana and the United Kingdom, and which left him paralyzed from the waist down. His paralysis prevented him from returning to Ghana to establish his business, since following his divorce he resided alone and required assistance on a day-to-day basis and regular medical care, which would have been difficult to organize in Ghana. Thanks to physiotherapy in a British clinic, he was eventually able to continue living in his flat in London. What was more, he learned to work at a computer, which was to become the centre of his activities for the next two decades. Previously too professionally engaged to write, his situation after the accident afforded him the time to work at his longstanding book projects. Just as important, perhaps, was that his scholarly activities presented him with a new purpose in life. Hence, he set out to write an extensive autobiography as well as rework an earlier manuscript, titled 'Gandah-yir, the House of the Brave', that traces the history of his family and particularly his father, the Birifu Naa.

Unfortunately, Kum's premature death from a heart attack in 2001 prevented him from completing these manuscripts. But what he left are two fascinating long texts that artfully interweave personal memoirs with reflections on the wider cultural and political developments in which his own and his family's history were embedded. The autobiography (Gandah 2004), published posthumously with the 
support of Kumbonoh's long-time friend and research associate, the Cambridge anthropologist Jack Goody, contains a detailed account of the first thirty years of his life. ${ }^{1}$ Its title, The Silent Rebel, was Gandah's own choice, a reference to his refreshing disrespect towards school (and other) authorities. The autobiography offers a wealth of information not only about Kum himself and his experiences at school and during holidays spent in the village, but also about his age cohort, a group of young men from the north-west who would later define regional politics and also influence events in the national arena.

'Gandah-yir', on the other hand, of which excerpts are presented below and the full text in the online version of this issue of the journal, has a more local focus. It narrates the story of Kumbonoh's father and his relations with villagers and neighbouring chiefs as well as the colonial officers who were stationed in the district capital Lawra, or passed through Birifu on their tours of inspection. Through the lens of Gandah's story, we learn about how Birifu was settled and how the immigrating patriclans spun their social networks, about the bagre initiation cult, about illness and indigenous medicine, divination and witch hunts, about the extensive 'trade' in ritual protection that developed around the Gandah-yir's Kukpenibie shrine, and, most importantly, about the colonial encounter in this part of the Northern Territories of the Gold Coast. We meet some of the district commissioners and the agricultural officer, we are given a lively account of Princess Marie-Louise's visit to Birifu and of the warlike rituals that Chief Gandah invented to greet his official visitors, and we listen in on court cases examining murder charges, chiefs' discussions about the benefits and problems of Western schooling, and the difficulties experienced by the colonial Medical Field Unit in clearing the sacred groves during their tsetse fly eradication campaigns. In short, the 'Gandah-yir' story opens a window on everyday life under colonial rule, albeit not from the perspective of the ordinary villager, but rather that of a chief who quite successfully juggled the expectations of colonial administrators, his own power interests and the welfare of his subjects. At the same time, the story is punctuated with the author's reflections on the efficiency of indigenous cures and their relation to Western medicine, the value of oral tradition and local memory versus documents penned by colonial officers, and the rationality of indigenous beliefs that the Catholic missionaries refused to appreciate.

In what follows, I will sketch Kumbonoh Gandah's development as a writer and local historian. I will then discuss his ambivalent perspective on Gandah-yir's life, as both a loyal son full of 'adoration' for his father, as he puts it, and a critic of many aspects of village life - a perspective typical of indigenous intellectuals who are members of that first generation of school graduates who embodied both a traditional upbringing and new values instilled through Western education.

\footnotetext{
${ }^{1}$ Kumbonoh gave Jack Goody as well as me copies of the Silent Rebel manuscript for review. As a result several manuscripts were in circulation. Yet, when the final version was collated for publication, it seems that neither Jack Goody nor the publisher noticed that a large part of the manuscript was missing, namely the account of the years between 1940 and 1947 during which Kum attended Tamale Government Middle Boarding School and Teacher Training College and established his networks with northerners, which would later become so important to his political career. I therefore decided to edit and publish the manuscript dealing with the 'missing years' (Lentz 2008) referred to in the title of this supplement to Kum's autobiography.
} 
Finally, I will look at Kumbonoh's own reflections on the task that he has set himself, namely reconciling oral tradition, local memories, and written history in an attempt to produce a historical account not only for his immediate family and the wider Dagara community, but for 'any reader in Ghana and abroad', including 'future researchers, anthropologists and historians alike', who would want to gain 'an insight into the society in which my father grew and was brought up during his lifetime'.

\section{THE FORMATIVE YEARS: BECOMING A WRITER AND LOCAL HISTORIAN}

As Kumbonoh explains in his preface, he grew up listening to his father's recollections and stories about the family ancestors, olden days in Birifu, and the time 'when the white man came'. Initial interest in these narratives had been instilled by his primary school teacher, who asked the students to collect local oral traditions. But it was not until Kumbonoh attended teacher training college that he was encouraged to write down some of his father's tales. His English teacher at the college introduced her students to the legend of Beowulf, that grand old English epic poem, and asked them to compose an essay featuring the heroes of local history. However, despite his great desire to document his father's life and the teacher's interest in his writing, Kumbonoh did not follow up on this first essay; other interests and concerns proved more pressing. Moreover, he did not feel the standard of his English was sufficiently high to warrant its publication.

It was not until he went to Britain that his desire to write reawakened, and his confidence regarding his ability to write grew. However, the subject he initially tackled was not the life history of his father, but a contribution on the development of 'Road transport in the Northern Territories of the Gold Coast' - a theme closely related to his interest in economics as well as his own experiences as a student, businessman and politician who had travelled extensively. But the manuscript never developed beyond the initial pages, perhaps because the topic was too far removed from his biography, and based more on archival work than the oral histories narrated in his home region.

It was his friendship and professional collaboration with Jack Goody, who had done fieldwork in Birifu in the early 1950s, that eventually rekindled his interest in writing about his father. Indeed, Kumbonoh met Goody, according to the latter's recollections (Goody 2004: 7-8), during his father's final funeral rites. However, since Kum was stationed in Tumu and travelled a lot due to his engagement in business and politics, he never worked as Goody's field assistant. In fact, the two did not see much of each other until the late 1960s, when Goody invited Kum, now living in London, to Cambridge to collaborate with him on the preparation of his book on The Myth of the Bagre (Goody 1972). In 1969, Goody and Kumbonoh returned together to Birifu to record another version of the bagre myth. The bagre is the most important 'secret' association among the Dagara and Dagaba of north-western Ghana. The initiation lasts several months and ends around Christmas-time with a large public feast; the long recitation of the bagre myth, however, takes place in a secluded room where only the old and new initiates are admitted. Kumbonoh himself was initiated into the bagre during his early childhood, and, according to what he told me, during the 1969 performance 
in Birifu managed to smuggle a tape recorder into the bagre room, while Goody had to remain outdoors. In 1974-5 and 1976-7, Kumbonoh returned to Lawra to make further recordings of bagre recitations, this time performed by a patriclan different from his own, but where he was admitted to the final ceremonies because of his status as bagre initiate.

During the years that followed, Goody and Kumbonoh collaborated in transcribing, translating and commenting on the bagre myth recitations, and coauthored two volumes that presented the performances recorded in 1969 and the late 1970s respectively (Goody and Gandah 1980; Goody and Gandah 2002). During this time, as Kumbonoh relates in the preface to 'Gandah-yir', he showed Goody his outline of the 'Road transport' manuscript, but was persuaded instead to return to work on his earlier essay about his father's history, to which Goody promised to contribute a few chapters on the basis of his own field notes on Birifu and its chief. Encouraged by the prospects of writing a book that would eventually be published, Kumbonoh devoted all his time after work to writing 'Gandah-yir', while Goody's secretary typed the first draft, and Goody read the manuscript, 'making as many suggestions as was found necessary to a complete novice like me in the art of writing a book', as Kum puts it. Ultimately, however, the manuscript remained unfinished because Kumbonoh's time and energy were eventually completely absorbed by the joint bagre project. Furthermore, even after completing his publications on the bagre, Goody never revisited his field notes on the history of Birifu and its chief, but embarked on themes that were far removed from north-western Ghana.

It was not until after his retirement, the accident and his physiotherapy that Kumbonoh turned again to his own abandoned book projects, now applying his newly acquired computer skills. The first text that he undertook to write, however, was not an expanded version of his father's biography, but the story of his own life. For quite some time, he had thought about writing down his experiences as village boy, student and party secretary, but initially, as he explains in the preface to The Silent Rebel, 'I felt my life was not worth a historical account being of insufficient importance either locally or nationally' (Gandah 2004: 11). However, over the years, as his family began looking to him 'more and more for leadership', he considered that 'something about me should be known' - an endeavour that gained urgency with his near-fatal accident. 'Having got the flair for wordprocessing, I decided to put on paper the simple story of my life. But in doing so it did not turn out to be as simple and straight forward as I had thought' (ibid.), not least because Kumbonoh aspired to make his account 'useful', not only to his extended family but also to the wider world. Eventually, the autobiography developed into an elaborate text of almost three hundred pages that artfully interweaves an account of Kum's personal story with a much broader narrative about the emergence of the first generation of northern Ghanaian teachers, professionals and politicians. The Silent Rebel, as Jack Goody (2004: 9) puts it in his foreword to the posthumously published volume, offers rare insights into the world of this new 'middle class' that 'encompasses both the traditional and the "modern".

When I met Kumbonoh in London in 1993 and expressed my keen interest in the history of chieftaincy in Lawra District, he mentioned the existence of the unfinished 'Gandah-yir' manuscript and allowed me to go through it. In return, I gave him copies of all the documents I had culled from the colonial archives in 
London, Accra and Tamale that contained references to Birifu and his father. Much as in the case of his collaboration with Goody, our exchange of ideas and materials encouraged Kumbonoh to rework and expand his manuscript. Soon, however, he decided to concentrate on first finishing his autobiography, which eventually took up all his energy, and we resolved to revisit the Gandah-yir project after the publication of The Silent Rebel. But unfortunately, Kumbonoh's premature death in 2001 prevented the realization of our plan.

I have hesitated for some time to go ahead with the publication of 'Gandah-yir', because I felt the manuscript needed somewhat more editing than The Silent Rebel and because the two texts had a certain amount of overlap, with some episodes appearing in both. When I recently re-read 'Gandah-yir', however, I discovered that the text was in fact not simply a straightforward narrative biography of Kumbonoh's father, but adopted an interesting reflective perspective that differed considerably from the autobiography. 'Gandah-yir' is significant in that it is one of the rare instances in which a lay historian writes a local history that takes seriously both oral traditions and archival documents and aims at bringing them together in a fascinating account of the story of a colonial chief and of the society in which he lived. As such, it is a valuable contribution to the history of colonial rule and chieftaincy in Ghana, and certainly merited publication, not least because northern Ghana, and the Upper West Region in particular, continue to be underrepresented in Ghanaian historiography.

Both manuscripts, then, were written in close interaction with Western-trained scholars and university academics, and the questions that Jack Goody and I raised in the course of our many conversations with Kumbonoh, as well as our editorial suggestions, certainly influenced his perspective to some degree. However, as the author self-confidently explained, where Goody's 'corrections changed the entire sense of what I was trying to say, I still allowed my original sentence to stand or changed my sentence in such a way as to retain the original meaning' (Gandah 2004: 12). Similarly, with regard to 'Gandah-yir', Kumbonoh insisted on his father's or his own version of historical events and defended them tenaciously against any interpretation that I might have offered on the basis of my reading of the written sources or interviews with other elders from Birifu or Lawra. Kumbonoh Gandah keenly embraced whatever additional information he found useful and convincing, without ever devaluing his father's and other village elders' knowledge that was validated by sources of authority quite different from those of Western-trained academics. As writer, too, he remained, to a certain extent, a silent rebel, creating a unique synthesis of oral tradition, local memory and modern historiography.

\section{RECOUNTING CHIEFTAINCY, COLONIAL RULE AND GANDAH-YIR'S SPIRITUAL POWERS}

Kumbonoh Gandah's narrative leaves no doubt that 'Birifu had no chief as such before the advent of the white man' (19). ${ }^{2}$ Focusing on the story of his father, however, the author does not tell us much about Derkota, the first Birifu chief,

\footnotetext{
${ }^{2}$ Page numbers refer to the online PDF document of the 'Gandah-yir' manuscript.
} 
except that he belonged to the same patriclan as Gandah and was made chief because 'his family ... gave hospitality to the first white man who visited the village' (19). In other villages of Lawra District, where I reconstructed the local history of chieftaincy, such hospitable houses were often those of local strongmen who did not fear to interact with strangers because they could mobilize enough warriors to defend themselves or had gathered some experience in the wider world as traders or slave owners. We may assume that Derkota, too, was a powerful man, heading a large household.

In any case, it was by interacting with local actors who were themselves interested in political centralization and power that the British succeeded in transforming the political landscape. By 1907, colonial officers had divided Lawra District into ten 'native states', as they called these chiefdoms, of which some encompassed up to thirty settlements, while others included only two or three, each native state being subject to a head chief. Birifu was one of these smaller native states, which in the early 1930s were then integrated as subdivisions into the four largest entities, Lawra, Jirapa, Nandom and Lambussie. The Lawra Confederacy, which was created during this time out of these four divisions, survived the administrative reforms of the 1950s and continues to serve as the framework within which local political alliances and enmities are entered into and the establishment of new districts and constituencies is disputed. ${ }^{3}$

In many respects, Birifu Naa Gandah stands at the threshold of a transition from a first generation of 'strongman' chiefs who knew how to manipulate power networks through gifts, violence and spiritual authority, to a second generation of 'civil servant' chiefs who were capable and at the same time obedient administrators and allowed themselves to be incorporated into the colonial bureaucratic hierarchy. Gandah was made chief in 1917, after the new political order of chiefdoms had been more or less firmly established in Lawra District. 'Pacification' - the suppression of local feuds and attacks on traders or colonial officers - was the major concern of the British administration until the First World War, and 'strongman' chiefs with their strategies of patronage, predation and redistribution were useful allies in achieving these aims. In the post-war period, the emphasis of British policies shifted towards infrastructural development and the recruitment of labour for the Gold Coast Colony and the Ashanti Protectorate, and this required a new type of indigenous ruler.

The author narrates with much filial admiration how his father went about establishing a 'modern' chiefdom and bringing 'development' to his people. Even though Gandah never learnt English or went to school himself, the reader may still discover here certain parallels with modernizing colonial chiefs in southern Ghana, of whom Nana Sir Ofori-Attah of Akyem Abuakwa is a well-known example (see Rathbone 1993: 21-67). Gandah systematically gathered information on births, deaths, illnesses and labour migration among his villagers. He introduced improved techniques of road maintenance and experimented on his own farms with bullock ploughing, intending this to serve as a model for other villagers. He willingly collaborated with the colonial authorities in disease control and energetically assisted the recruitment of soldiers for the Second World War. He became an efficient tax collector and supported the establishment of the

${ }^{3}$ For a fuller account of these developments, see Lentz 2006: 33-71, 104-37. 
Lawra Confederacy Native Authority's primary school, propagating the blessings of modern education not least by sending eight of his own sons to school. Many of these policies demanded a considerable exertion of 'free' labour, or the provision of produce or cash, by his subjects. However, as Kumbonoh insists, his father made sure that onerous tasks and exactions were distributed in such a way that the families always retained enough labour to farm for themselves. In short: Gandah attempted to balance the colonial officers' demands and his subjects' welfare, but obviously also did not miss out on the opportunities that his office afforded him to amass considerable wealth.

How the villagers themselves experienced Gandah's rule, and whether his redistributive measures and development efforts managed to legitimate his rather spectacular accumulation of wives, offspring, cattle and other riches, are questions which the manuscript, for obvious reasons, cannot answer. The intensity with which the author repeatedly emphasizes the rationality of Gandah's policies and their contribution to the public good is perhaps indicative of a certain anxiety that the chief's rule may indeed be judged as exploitative. Kumbonoh also explains on several occasions that the Gandah family furnished a disproportionate number of students at Lawra Confederacy Native Authority Primary School, not because his father would have insisted on any privilege for the chiefly family, but to act as a good example, since other villagers were not willing to send their children to school.

Throughout his account, the author leaves not the least doubt that his father was not a victim of colonial rule, but rather an actor in his own right, adopting 'development' as his own project, not a colonial imposition, and interacting with the district commissioners without any sign of servility. Much of the book's historical and scholarly value lies precisely in this perspective on a northern chief who is shown to take centre stage and meet the colonial administrators on an equal footing. Occasionally, the book does underwrite the conventional narrative of colonialism as European intrusion, propelled by 'greed' and the European states' interest to 'extend their empires' (14). But wherever Kumbonoh recounts his father's life, abstract colonialism is broken down into concrete encounters with specific British officers who had their different personalities and ways of treating the local population and the chiefs.

In passing, Kumbonoh makes a most revealing remark, namely that as late as the 1930s, his father 'believed that the white man would soon return to his native country' (37). Because of this expectation, Kumbonoh argues, Chief Gandah never relied on cooperation with the British alone, but also aimed at building his own power base and trained the youth in the art of archery. But because he 'believed in the powers of the supernatural' (37), prowess in warfare alone was not sufficient. The Gandah family does not belong to the earth-priestly house that controls one of the most important shrines for fertility and protection in the village, namely the earth shrine. However, Gandah availed himself of all other avenues of spiritual protection, ranging from regular sacrifices at traditional ancestor shrines - as well as shrines to the rain god, river spirit and other local bush deities - to membership in the bagre cult and, finally, the acquisition of all manner of talismans, ointments and medicines from itinerant Muslim traders and scholars. Some of these jujus, as the author terms them for want of a better word, served Gandah's personal protection, others were to protect the entire family and the village at large. Gandah was 'known to be one of the greatest juju men in the 
North of Ghana' (37), Kumbonoh proudly states, and, whatever the veracity of this judgement, Gandah's spiritual expertise and command of medicines and shrines were certainly an important base of his power.

The most important shrine that Gandah controlled was the Kukpenibie, literally: 'I shall not cohabit with the evil doer'. Kukpenibie was a 'god', in Kumbonoh's words, 'against evil, a god which brings riches to whoever desires and asks for it, a god that gives fertility to barren women and hence a god for the protection of children' (39). The author does not tell us when and from whom Gandah acquired the Kukpenibie, but we are informed that as early as the 1920s, the renown of Kukpenibie had spread far enough to attract two Ashanti brothers from Kwapra who travelled to the north in their search for a powerful 'fetish' to grant them material wealth, fertility and a long life (50-3). The brothers even managed to bring Gandah on a visit to their village so that he could install the shrine that was later to become known under the name of Kakama and develop into an important anti-witchcraft cult. ${ }^{4}$ The increasing traffic in ritual protection that brought a constant stream of visitors to Birifu provided Gandah with an important source of income, and it helped to create a far-reaching network of new friends whose support proved valuable, for instance, when Gandah's sons set up their transport business.

Kumbonoh's account of his father's spiritual powers and his manifold encounters with witchcraft pays due respect to what was probably Gandah's own perspective on these matters, taking the 'supernatural' as a given and recounting, for instance, the detection and persecution of witches rather matterof-factly. On the other hand, however, Kumbonoh repeatedly emphasizes 'the more scientific qualities' (39) of his father's knowledge and skills. He insists that his father was not only a 'clairvoyant' and diviner, but also knew, on the basis of his rich experience in observing nature, how to forecast the weather. He describes his father as 'a physician and an herbalist in his own right' (39), and explains that the efficiency of some of his herbal cures for widespread diseases was even acknowledged by the colonial medical officers, but that his father unfortunately refused to disclose his knowledge to these outsiders. Kumbonoh thus suggests that many of his father's cures were, in fact, based on knowledge of plant properties and the human body that could well stand up against modern, natural sciencebased medicine.

In a few instances, Kumbonoh takes a pronounced stand against local theories of witchcraft as the cause of illness. Concerning the death of his mother, for instance, he insists that she died from whitlows and septicaemia, not from the results of witchcraft, as many in the house and, most importantly, his father believed. 'For no theory of witchcraft will stand the test of time in this day and age', Kumbonoh comments, but 'as an oral historian, I have to recount what has been told me and let the readers judge for themselves' (59). When he relates his father's experiences in seeking a cure for his failing eyesight, he does not spare biting criticism of the "quack physicians who would only be there to fleece him of his money with their fake medicines' (99). At the same time, Kumbonoh wants to make the reader understand and sympathize with the rationality of the

\footnotetext{
${ }^{4}$ There are interesting parallels with the case of 'Nana Tongo', a Tallensi ancestor shrine that became the base of an intricate Ghana-wide ritual network; see Allman and Parker 2005.
} 
convictions and the perspective of his father and the villagers. He argues that because some of the Western-trained expatriate doctors had little knowledge concerning tropical diseases, their measures were not always effective and must have seemed rather irrational to local people. And he is highly critical of the arrogance that colonial officers, doctors and missionaries displayed vis-à-vis local systems of belief. He refuses to accept the stigmatization of his father and other Dagara as 'pagans' and insists that they followed a 'faith' and local 'religion' that was as valuable as the Catholicism that the White Fathers attempted to bring to Birifu.

In sum, just as Kumbonoh does not treat Gandah as a victim of colonialism but shows his father and the colonial officers as having engaged on equal standing, he insists that the Birifu people and the Dagara at large 'had a civilization of their own' (17) and that local ways of life and European modernity should be treated on a par. From The Silent Rebel we know that school education during colonial times often imparted a sense of the superiority of things Western. In a way, then, 'Gandah-yir' is an admirable attempt to rebel against colonial stereotypes of local belief systems, and to reconcile modernity with indigenous traditions. In many respects, the author adopts an anthropologist's perspective, defending the reasonableness and wisdom of local culture. Yet he may also pay the price this perspective implies-namely, making the 'other' appear all too rational and familiar.

\section{THE WRITING OF HISTORY: ORAL TRADITION, LOCAL MEMORY AND COLONIAL DOCUMENTS}

A similar attempt to reconcile local and Western perspectives characterizes the way this book treats oral tradition, local memory and written history, or, to be precise, colonial documents. It is interesting that Kumbonoh mentions the English epic poem Beowulf as a source of inspiration (2), because there is a lively debate about the extent to which this legend was formed by oral tradition. Was Beowulf an orally composed poem handed down over generations and eventually transcribed, or was it from the very beginning a piece of literature written by a monk who deliberately recreated the heroic language of ancient oral poetry? In the case of 'Gandah-yir', the author leaves no doubt that his major sources were the stories that his father told, stories of both oral traditions he had heard from his forebears and of events he had experienced himself (1-2). And wherever colonial documents deviated from these stories, Kumbonoh states, 'I still maintain the oral version of my father's narration' (4).

This loyalty to his father's accounts notwithstanding, the author engages in an interesting reflection about the nature of archival data and their potential bias. They are unreliable, he believes, mainly because the colonial officers had a limited understanding of local ways of life, and because 'some of the early recorders of the data did not have the same definition of words used or the same titles given to persons. In some places, the same person was described as a chief, head chief or headman' (5). But if, Kumbonoh convincingly argues, 'the written documents are used together with the oral evidence from those who have lived through the period ... the researcher should be able to gain more insight' (5). Kumbonoh's account of the early chiefs' conferences in Lawra District (34-5) and the 
recognition, during one of the durbars, of his father's role in fighting the 1918 meningitis epidemic (44-5) would seem to rely heavily on written documents. The author's attempt to date the arrival of the first 'white man' to Birifu, on the other hand, is an example of his determination to maintain his own theory despite the absence of supporting documentary evidence (14).

At the same time, Kumbonoh is acutely aware that oral history is in itself not altogether unbiased, but characterized by sometimes complementary, sometimes competing accounts of the events in question. In the process of handing these stories down, he argues, 'each audience only catches the gist of what interests him or her, or what he or she wants to hear and listen to' (5). Like a professional historian, he therefore collected additional versions, for instance of the local settlement history and related themes, from an uncle and from some of his elder siblings, and then attempted to 'compare each of their versions for their veracity and consistency' (5). Wherever documentary evidence is missing, the author tries to calculate dates based on an estimation of the 'life span between a grandfather and a grandson' (7). More generally, he wants 'to put events in chronological order' (5), and takes care to place his father's story in a broader geographical and historical context. He discusses, for instance, the Gandah family's seventeenthcentury migrations as part of the larger context of 'a period full of turmoil, not only in Africa, but all over the world' (7), and often offers broader reflections on colonial rule, the missionary endeavour or the advances of medicine. It is not least thanks to these engaging discussions that remain anchored in the intricacies of the local Dagara world while linking Gandah's story with broader debates on power, religion, modernity and the value of tradition that 'Gandah-yir' makes such fascinating and rewarding reading.

\section{ACKNOWLEDGEMENTS}

The 'Gandah-yir' manuscript was first published as a Research Review Supplement No. 20 by the Institute of African Studies, University of Ghana, Legon (S. W. D. K. Gandah, 'Gandah-yir: the house of the brave. The biography of a northern Ghanaian chief (ca 1872-1950)', edited by Carola Lentz. Legon: University of Ghana, 2009). I express my sincere thanks to the editor of the Research Review, Professor Albert K. Awedoba, and his editorial committee for their permission to reprint Gandah's text in this issue of Africa. Great thanks are also due to Professor Mary Esther Kropp-Dakubu, also at the Institute of African Studies, University of Ghana, who originally encouraged me to publish the text as part of the Institute's research papers series. A sabbatical in 2008-9, supported by a Fulbright travel fellowship, brought the long-awaited opportunity to edit the manuscript that Kumbonoh had left in my hands shortly before his untimely death. The W. E. B. Du Bois Institute for African and African American Research and the Harvard University Committee on African Studies provided a congenial intellectual environment that facilitated my work. In preparing the text for publication, the help of Mareike Späth in Mainz was invaluable, and Katja Rieck helped with the copy-editing of my editorial introduction. In Africa's on-line version of Gandah's manuscript, the original introduction is also reproduced; it differs from the introduction published here (in print) in that it devotes more space to the history of chieftaincy as well as to Birifu Naa Gandah's 'trade' in spiritual protection - themes that Gandah's full manuscript addresses in great detail and that, in order to be understood beyond the local context, needed some editorial explanation.

Warmest thanks must go out to the members of the Gandah family who kept me up to date with developments in Birifu and London; to them I am profoundly indebted. Finally, a few words in fond memory of my friend and mentor Kumbonoh. It was in 1993 that we first 
met, and I was impressed by the precise memory, sharp analyses and wonderful sense of humour with which he recounted the political developments in the north-west during the 1940s and 1950s. Moreover, I was and still am deeply grateful that he was willing, and even eager, to share his knowledge and experiences with me. Over the years, we spent endless hours talking, on the phone and in person, discussing the projects, biographies and experiences of the educated elite of northern Ghana, party politics, chieftaincy, family affairs and conflicts. Most importantly, knowledge of history and local traditions was in Kumbonoh's eyes not something that should be reserved exclusively for one's own family, village, or ethnic group, but rather should be shared freely irrespective of the boundaries of class, nationality or race. It is to this legacy that I hope the publication of 'Gandah-yir' remains true.

\title{
REFERENCES
}

Allman, J. and J. Parker (2005) Tongnaab: the history of a West African god. Bloomington IN: Indiana University Press.

Gandah, S. W. D. K. (2004) The Silent Rebel. Accra: Sub-Saharan Publishers (for the Institute of African Studies, University of Ghana).

Goody, J. (1972) The Myth of the Bagre. Oxford: Clarendon Press. - (2004) 'Editor's introduction' in S. W. D. K. Gandah, The Silent Rebel. Accra: Sub-Saharan Publishers.

Goody, J. and S. W. D. K. Gandah (1980) Une réctitation bagré. Paris: A. Colin. (2002) The Third Bagre: a myth revisited. Durham NC: Carolina Academic Press.

Lentz, C. (2006) Ethnicity and the Making of History in Northern Ghana. Edinburgh: Edinburgh University Press and the International African Institute.

(ed.) (2008) 'The silent rebel: the missing years. Life in the Tamale Middle School (1940-47), by S. W. D. K. Gandah'. Research Review Supplement 18, University of Ghana, Institute of African Studies, Legon.

Rathbone, R. (1993) Murder and Politics in Colonial Ghana. New Haven CT: Yale University Press.

\begin{abstract}
S. W. D. K. Gandah was the son of an influential chief and witnessed first-hand the way the conflicts, pressures and transformations of colonial rule played out on the ground in northern Ghana. Belonging to the first generation of educated northerners, he put his literary and intellectual attainments to original use throughout his life. In addition to an autobiography (The Silent Rebel), he wrote a fascinating history of his father (Gandah-yir), extracts from which are published here. In this introduction I discuss the author's development as a writer and local historian. I analyse his ambivalent perspective on Chief Gandah's life, as loyal son, but also critic of many aspects of village life - a perspective typical of a first generation of indigenous intellectuals who embodied both a traditional upbringing and new values instilled through Western education. I look at Kumbonoh's reflections on the task that he has set himself for his Gandah-yir manuscript, namely reconciling oral tradition, local memories, and written history in an attempt to produce a historical account not only for his immediate family and the wider Dagara community, but for a broader readership.
\end{abstract}


S. W. D. K. Gandah, fils d'un chef influent, a été le témoin direct des conflits, des pressions et des transformations du régime colonial qui se sont joués sur le terrain dans le Nord du Ghana. Appartenant à la première génération d'instruits dans cette région, il a consacré ses œuvres littéraires et intellectuelles à ces origines tout au long de sa vie. Il est l'auteur d'une autobiographie (The Silent Rebel), mais aussi d'un récit fascinant sur son père (Gandah-yir) dont cet article publie des extraits. Dans cette introduction, l'article retrace le cheminement de l'auteur en tant qu'écrivain et historien local. Il analyse sa perspective ambivalente sur la vie du Chef Gandah, en tant que fils loyal mais aussi de critique sur de nombreux aspects de la vie de village; une perspective typique d'une première génération d'intellectuels indigènes qui incarnaient à la fois une éducation traditionnelle et des valeurs nouvelles inculquées par l'enseignement occidental. Il examine les réflexions de Kumbonoh sur la tâche qu'il s'est assignée pour son manuscrit Gandah-yir, à savoir de concilier tradition orale, mémoire locale et histoire écrite pour tenter de produire un récit historique s'adressant non seulement à sa famille immédiate et à la communauté Dagara, mais aussi à un lectorat plus large. 